\title{
Influence of pollution along a natural gradient and in a mesocosm experiment on biomass-size spectra of benthic communities
}

\author{
P. Schwinghamer \\ Department of Fisheries and Oceans, Science Branch, PO Box 5667, St. John's, Newfoundland, Canada A1C 5X1
}

\begin{abstract}
Biomass-size spectra of benthic communities at 6 sites in Frierfjord/Langesundfjord, Norway, and in 4 experimental mesocosm basins at Solbergstrand, Norway, are presented, as evaluated during the GEEP Workshop. Fjord sites were selected to represent a pollutant gradient based on known sources of pollution. Three of the mesocosm basins were exposed to different dosing levels of a mixture of diesel oil and copper for ca $3 \mathrm{mo}$; the 4 th basin served as control. Communities from the fjord sites showed differences in size-structure that could be related, in part, to their proximity to pollution sources. Mesocosm communities revealed no significant differences in size-structure attributable to dosing level.
\end{abstract}

\section{INTRODUCTION}

Studies concerning the effects of environmental pollution on marine communities are sometimes considered too time consuming and expensive given the often equivocal nature of their results (e.g. Hargrave \& Thiel 1983). Yet, if we are to assess biological effects of pollution at the community level we must gather information on pertinent community responses; in general, these cannot be extrapolated from population, physiological, biochemical or other 'lower level' effects. It remains necessary therefore to search for communitylevel phenomena which are both sensitive indicators of pollution effects and accessible to investigation under normal circumstances.

A feature of marine benthic communities that may be suitable in this regard is their size-structure. Marine soft-bottom benthic communities, regardless of their taxonomic composition, display characteristic patterns of distribution of biomass (Schwinghamer 1983, 1985, Gerlach et al. 1985) over the size spectrum ranging from bacteria to infaunal and epifaunal macrofauna. A mechanistic explanation of the most common pattern, which is a tri-modal distribution with biomass peaks corresponding to bacteria, interstitial meiofauna, and macrofauna has been offered by Schwinghamer (1983) but has yet to be verified experimentally. It is hypothesised that this pattern is imposed upon the community by the physical dimensions of the sedimentary benthic habitat which differ as a function of the scale of resolution. For example, bacteria live mostly attached to particle surfaces in the sediment matrix, interstitial meiofauna live in the fluid-filled spaces among the particles, and macrofauna perceive the sediment as effectively non-particulate. The biomass peaks appear to correspond to optimal sizes for each of these lifestyles; regions of lesser biomass signal size ranges where there is a shift of predominant lifestyles from one mode to another.

This hypothesis accounts for much of the observed variability in biomass-size spectra over a wide range of sediment types and predicts situations where one would expect the tri-modal distribution to break down. However, it does not attempt to relate the effects of stresses such as pollution to observed patterns of biomass-size distributions. There have been no observations to date which can be used to formulate even preliminary hypotheses, and general ecological theory offers few guidelines because it does not deal with interactions of populations over a broad size spectrum. Thus, although we expect that smaller animals will dominate the macrofauna in stressed communities (e.g. Gray 1982), this cannot yet be generalized over the entire size spectrum

The GEEP Workshop has provided an opportunity to observe the effects of anthropogenic stress on the size structure of soft-bottom benthic communities from southern Norway. Samples were taken from several 
sites in Frierfjord and Langesundfjord, and these were assumed to reflect a range of pollution impact resulting from contaminant inputs at the head of Frierfjord. In addition, a controlled contaminant-dosing experiment was performed at the Solbergstrand mesocosm facility, on sediment cores taken nearby in Oslofjord.

Benthic samples were taken for macrofauna, meiofauna and microbiota, including bacteria, microalgae and protists; the data generated are discussed by Gray et al. (1988), Heip et al. (1988), Schwinghamer (1988) and Warwick et al. (1988). This paper re-examines those data, recast into biomass-size spectra.

\section{MATERIAL AND METHODS}

Field sampling locations and depths are given by Follum \& Moe (1988, their Fig. 2). Samples for sediment meiofauna and microbiota were collected on 24 April 1986 using a Craib corer which sampled an area of 24.6 $\mathrm{cm}^{2}$ to a depth of $8 \mathrm{~cm}$. Macrofaunal samples had previously been collected on 21 and 22 January 1986 using a $0.1 \mathrm{~m}^{2}$ Day grab (Gray et al. 1988).

In the mesocosm experiment at Solbergstrand, 5 box cores of undisturbed sediment (area $0.25 \mathrm{~m}^{2}$ ) were placed in each of 4 basins, fed with seawater from Oslofjord. Three of the basins received a mixture of diesel oil and copper in different dilutions, designated low dose (L), medium dose $(\mathrm{M})$ and high dose $(\mathrm{H})$, with the 4 th basin serving as control (C); dosing commenced on 24 April (Bakke et al. 1988). Core samples similar to those taken in the field for meiofauna and microbiota were taken on 29 May and 7 July, from 4 boxes of sediment in each of the 4 experimental basins. Only the July results are considered here. Duplicate macrofaunal samples were collected from the same boxes on 21 July using $9.3 \mathrm{~cm}$ diameter cores to a depth of $30 \mathrm{~cm}$ (Gray et al. 1988). On 29 July sediment remaining in these boxes, to a depth of $10 \mathrm{~cm}$, was sieved through 1 $\mathrm{mm}$ and $5 \mathrm{~mm}$ sieves and this macrofauna was included in the final biomass estimates. Subsampling, preservation and storage protocols for microbiota, meiofauna and macrofauna from both field and mesocosm studies are given in Gray et al. (1988), Heip et al. (1988), Schwinghamer (1988) and Warwick et al. (1988).

Bacterial size distributions were measured to obtain the data presented by Schwinghamer (1988), using the methods described therein. Size measurements were not done on bacteria from all field samples due to time constraints but where they were done (1 sample each from Sites A, D and E) size distributions within the groupings used were similar. As in the mesocosm experiment, only the relative proportions of the groups changed markedly among samples. The microbial spectra derived from the field samples are therefore only reflections of total biomass levels distributed over 3 groups of organisms, according to an average distribution calculated from the samples measured.

Meiofaunal sizes in mesocosm communities were measured microscopically using a subsample of the first 100 organisms of metazoan meiofaunal taxa encountered on mounted slides. Heip et al. (1988) provided individual weight data for nematodes and volume data for copepods from the field samples. Weights were converted to volumes assuming a density of $1.13 \mathrm{~g}$ $\mathrm{cm}^{-3}$. Meiofauna from both mesocosm and field samples were collected on $63 \mu \mathrm{m}$ sieves and did not include protists. Therefore smaller meiofauna are under-represented in the size spectra constructed from these samples.

Macrofauna data for both field and mesocosm samples were in the form of numbers of individuals and total population wet weights per unit area for each species (Gray et al. 1988); they were converted to average individual volumes for each sample population using a wet-weight-to-volume ratio of 1.1, except for large, heavy-shelled molluscs whose wet weights were divided by 2 to approximate volume.

The methods of determining the size distributions were thus less direct and more approximate than those used by Schwinghamer $(1983,1985)$ but they provide comparative data within this study - data which are at least broadly comparable with those presented in previous studies.

Biomass-size spectra are presented on an octave scale of size, that is, each increment in size class represents a doubling of individual volume (Figs. 1 to 3). A shape-independent linear measure, the equivalent spherical diameter (ESD), is used on the axis of all spectra. Three size class increments (volume doublings) are equivalent to a doubling of ESD. In earlier papers, Schwinghamer $(1983,1985)$ used size classes based on ESD doubling to show broader-scale patterns of benthic size distributions. The biomass ordinates are in units of total volume $\left(\mathrm{mm}^{3}\right)$ per unit surface area of sediment $\left(\mathrm{cm}^{2}\right)$ to a depth of $8 \mathrm{~cm}$ in each size class.

Multidimensional scaling (MDS), a non-parametric ordination technique, was used to display differences and similarities in size structure within the bacterial and macrofaunal size ranges among the mesocosm treatments, and for macrofauna only among field sites. The significance of differences between sites was examined by the randomisation test ANOSIM; both this and MDS are described in Clarke \& Green (1988). Size classes are treated as if they were 'species' in constructing the MDS ordination, although they in no way represent biological species. Therefore, any discrimination among mesocosm basins or sites by MDS, on the basis of size structure, would be analogous to 
but independent of the results obtained by MDS using species abundances (Gray et al. 1988, Heip et al. 1988, Warwick et al. 1988). No comparative tests were performed on the overall size spectra because the data for field bacteria and meiofauna were not available in formats suitable for such tests, and sizes of the mesocosm meiofauna were measured only in high-dose and control treatments.

$E$

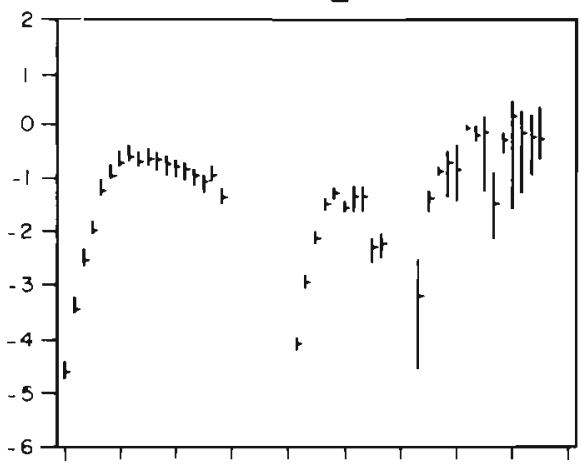

$\mathrm{F}$

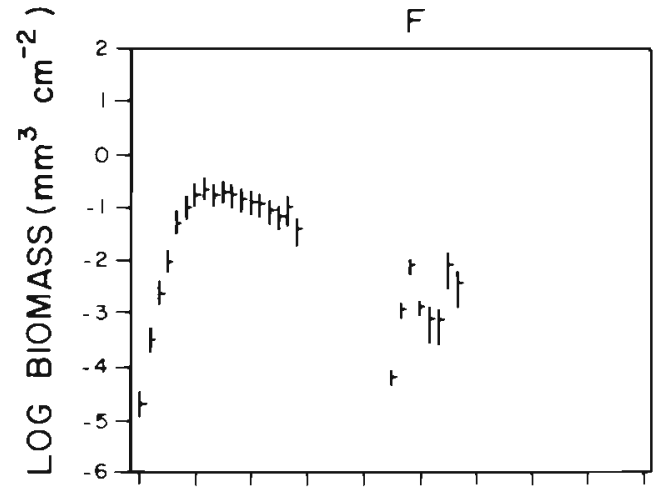

D

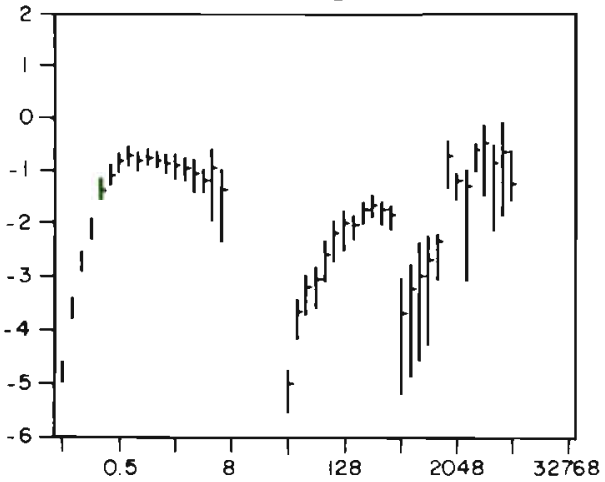

\section{RESULTS}

The Principal Component Analyses of Gray et al. (1988), Fig. 14, indicate some differences in sediment concentrations of both metals and polyaromatic hydrocarbons between the Frierfjord/Langesundfjord field sites. This is most noticeable for metals, in the lower levels at the reference site (A) and higher levels at $G$,

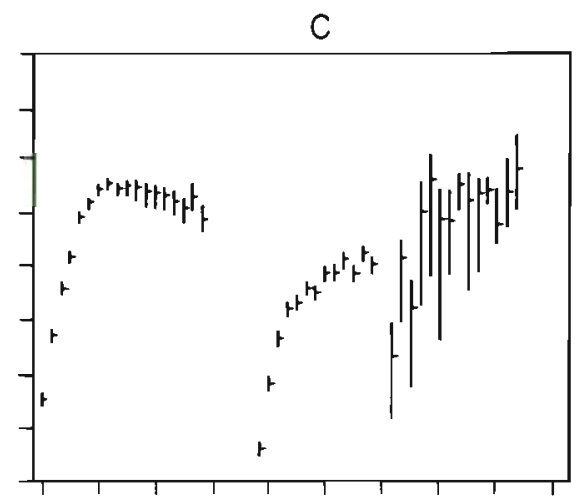

B

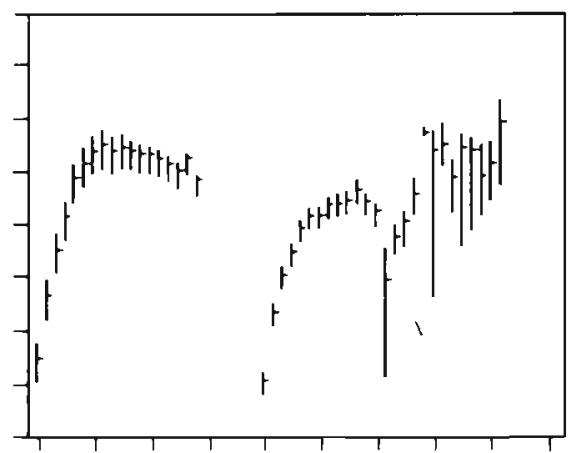

A

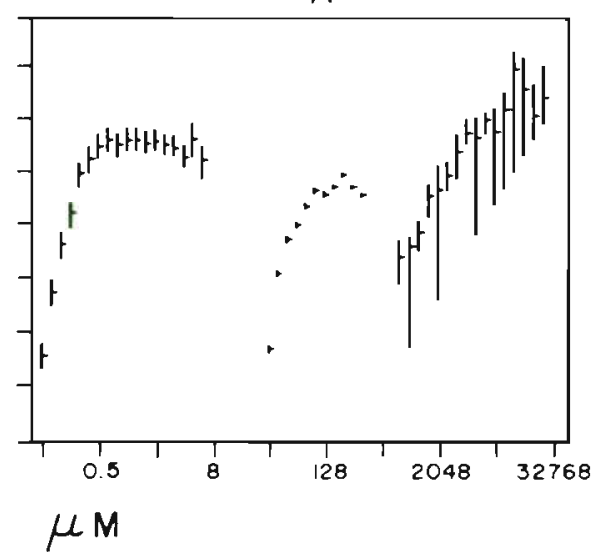

Fig. 1. Biomass-size spectra of benthic communities at 6 locations ( $A$ to $F$ ) in Frierfjord and Langesundfjord, Norway. Means and ranges of values in each octave scale size class in which biomass was measurable are illustrated 
though a clear pollution gradient uncomplicated by other environmental factors does not emerge. In the mesocosm experiment, similar multivariate analyses of the chemical data (Gray et al. 1988) appeared to show that, because of the limited duration of this experiment, the sediments in the treated basins failed to take up the dosed pollutants.

Results of the chemistry studies are reflected in the biomass size-spectra analysis, which showed trends in the field data but less differentiation for the mesocosm treatments. Along with comparisons among field sites and among mesocosm treatments, it is also instructive to compare biomass-size spectra from the mesocosm basins with those of field communities. There appear to be some experimental effects on the mesocosm communities that differentiate them from the field communities. Such comparisons, however, must be interpreted with caution because differences may also be due to sampling at different times of the year in the 2 regimes and to pre-existing differences between the Bjørnehodet Bay communities, from which the mesocosm samples were taken, and the Frierfjord/ Langesundfjord communities.

Figs. 1 and 2 illustrate the biomass-size spectra for field and mesocosm samples respectively. Fig. 3 shows spectra from the combined outer fjord sites (A, B, C), combined inner fjord sites (D, E, F) and combined mesocosm treatments. Means and ranges of values are given for each size class, except where no biomass was measured in any sample. In this case, no symbol is displayed for the size class. Where zero values are included in the ranges of macrofaunal size classes (from 512 to $32768 \mu \mathrm{m}$ ) the lower limit of the range represents a biomass value expected if organism density in that size class is 1 ind. $\mathrm{m}^{-2}$.

There appears to be an overall increase in biomass in most size classes along the inner-outer axis of the fjord system (Fig. 1), with the highest levels at the least impacted reference site (A). In the mesocosm basins (Fig. 2), there was no such trend. In fact, if anything, the reverse seems to have been the case - the higher the nominal dosing level, the higher the overall biomass levels in most size classes (however tests of significance of this were unsuccessful). Among field and mesocosm samples alike, there is one feature of the spectra that does seem to be related to inferred levels of pollutants. In Figs. 1 and 2, there is an apparent increase in 'bumpiness' of the spectra with increasing pollution; this is especially noticeable in the meio- and macrofaunal size ranges. Class-to-class trends are less

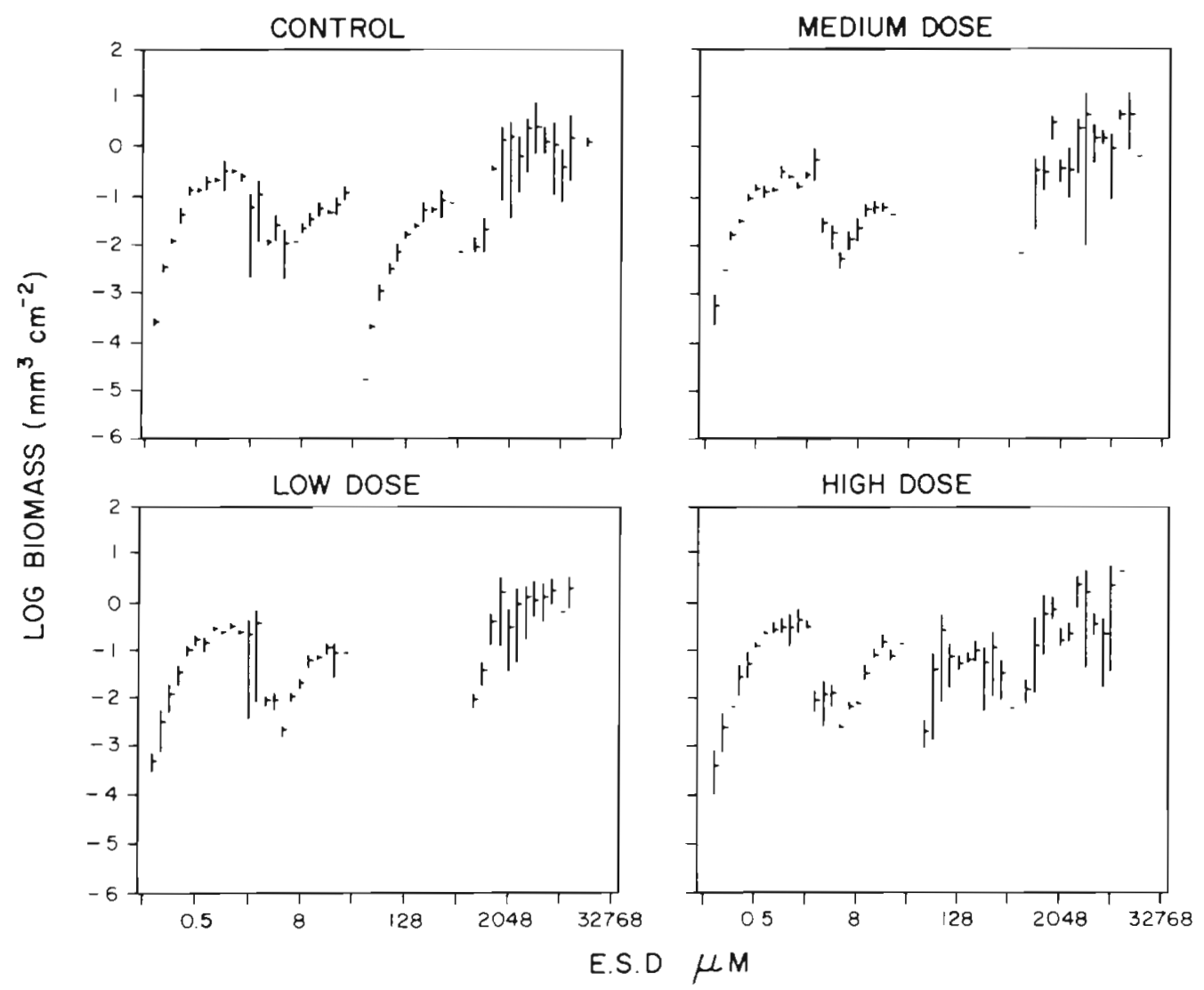

Fig. 2. Biomass-size spectra of benthic communities in the mesocosm experiment at Solbergstrand, Norway. Means and ranges of values in each octave scale size class in which biomass was measurable are illustrated 

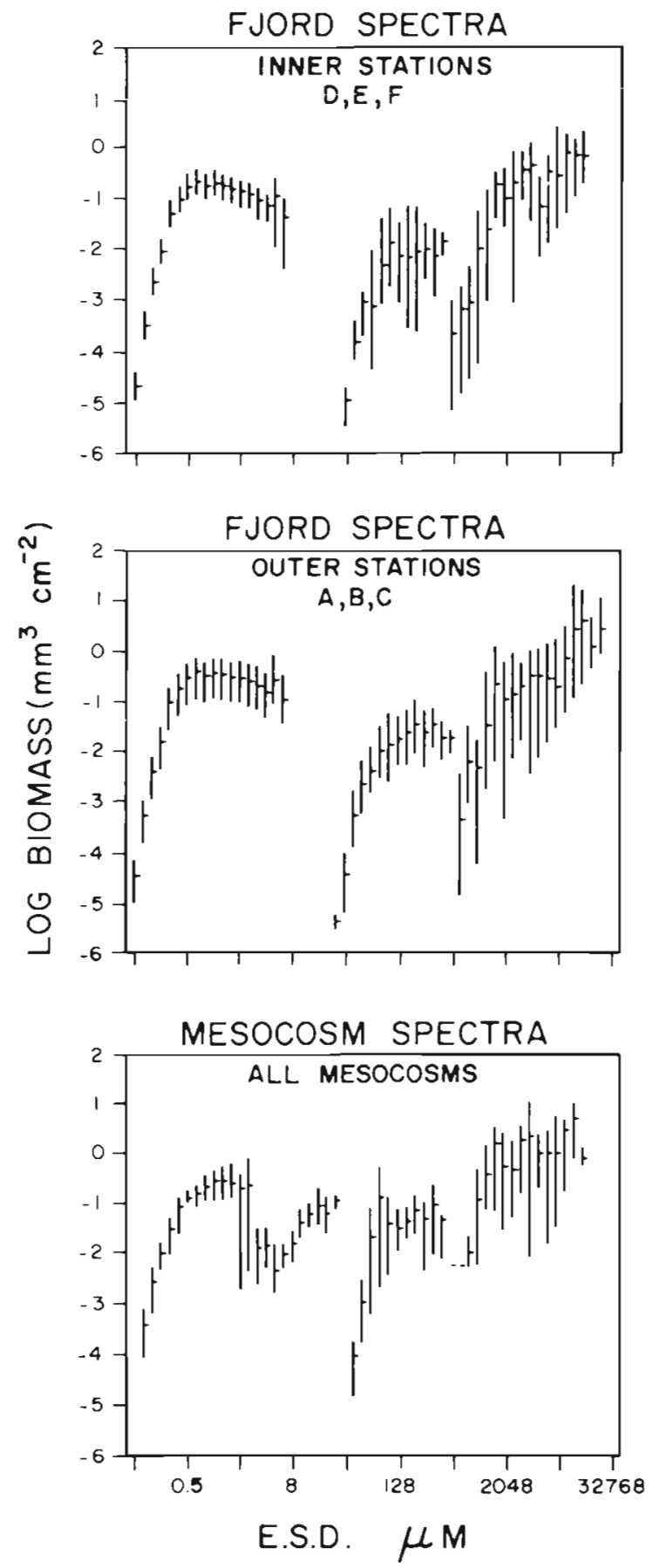

Fig. 3. Average biomass-size spectra of benthic communities, grouping inner and outer sites of the fjord system and all mesocosm basins. Means and ranges of values in each octave scale size class in which biomass was measurable are illustrated

consistently in one direction or the other, for Sites D, E and $F$ and in the high-dose basin, than they are for $A, B$, and $\mathrm{C}$ and the control basin.

As seen in Fig. 3, the outer fjord sites (A, B, C) had significantly higher total biomass in the bacterial and microflagellate groups $(0.125$ to $8 \mu \mathrm{m})$ than the inner sites (D, E, F), Schwinghamer (1988). Among the mesocosm basins, however, there were no significant differences in total biomass related to nominal dosing levels. ANOSIM tests for significant differences among mesocosm treatments, in the microbial range of the size spectra, also indicated negative results. As ANOSIM also gave no significant differences among biomasssize spectra in the macrofaunal size range in the mesocosms, all experimental treatments have been combined in Fig. 3 for comparison with field spectra. Bacterial and microflagellate size-classes up to ca $2 \mu \mathrm{m}$ are similar in biomass in the mesocosm and outer fjord samples, and both are generally higher than in the inner fjord samples. In size-classes between 2 and 8 $\mu \mathrm{m}$, the mesocosm samples exhibit low biomass relative to the smaller bacteria, while the field samples maintained high biomass up to $8 \mu \mathrm{m}$. Micro-algae were included in the mesocosm analyses but not in those of field samples, therefore size spectra between 4 and 32 $\mu \mathrm{m}$ cannot be compared in mesocosm basins and field sites. Micro-algae from the mesocosm sediments consisted mostly of pennate diatoms and had peak biomass in the size range 16 to $32 \mu \mathrm{m}$ (Fig. 2). Their biomass was always lower than that of microbial groups. The algae did not appear to respond in any clearly interpretable way to treatment effects in the mesocosm experiment (Schwinghamer 1988).

Meiofaunal analyses of both field and mesocosm samples included material retained on a $40 \mu \mathrm{m}$ mesh sieve. Only metazoans were measured and, in the field samples, only nematodes and harpacticoid copepods were included. Therefore, the meiofaunal spectra presented here range only down to the $32 \mu \mathrm{m}$ size class and underestimate the biomass in size classes where protists and metazoans other than nematodes and harpacticoids may be significant. Because a $500 \mu \mathrm{m}$ mesh was used to sieve macrofauna, there is little overlap in the size range adequately sampled for meiofaunal analysis and that adequately sampled for macrofaunal analysis. Thus, where polychaetes, ostracods, amphipods, etc. were not included in the field analyses, biomass in the larger meiofaunal and smaller macrofaunal size classes (256 to $512 \mu \mathrm{m}$ ) may have been underestimated. In addition, only control and highdose basins were analysed for the meiofaunal range of the size spectra. Low and medium-dose basins were not analysed because high-dose and control meiofaunal spectra did not differ significantly and because dose-related differences were not significant in the microbial or macrofaunal size ranges.

In spite of such limitations, it is still possible to find some interesting trends in the meiofaunal size range in the field samples, as well as some differences between field and mesocosm samples. Fig. 1 reveals a clear trend to higher biomass in all meiofaunal size classes as 


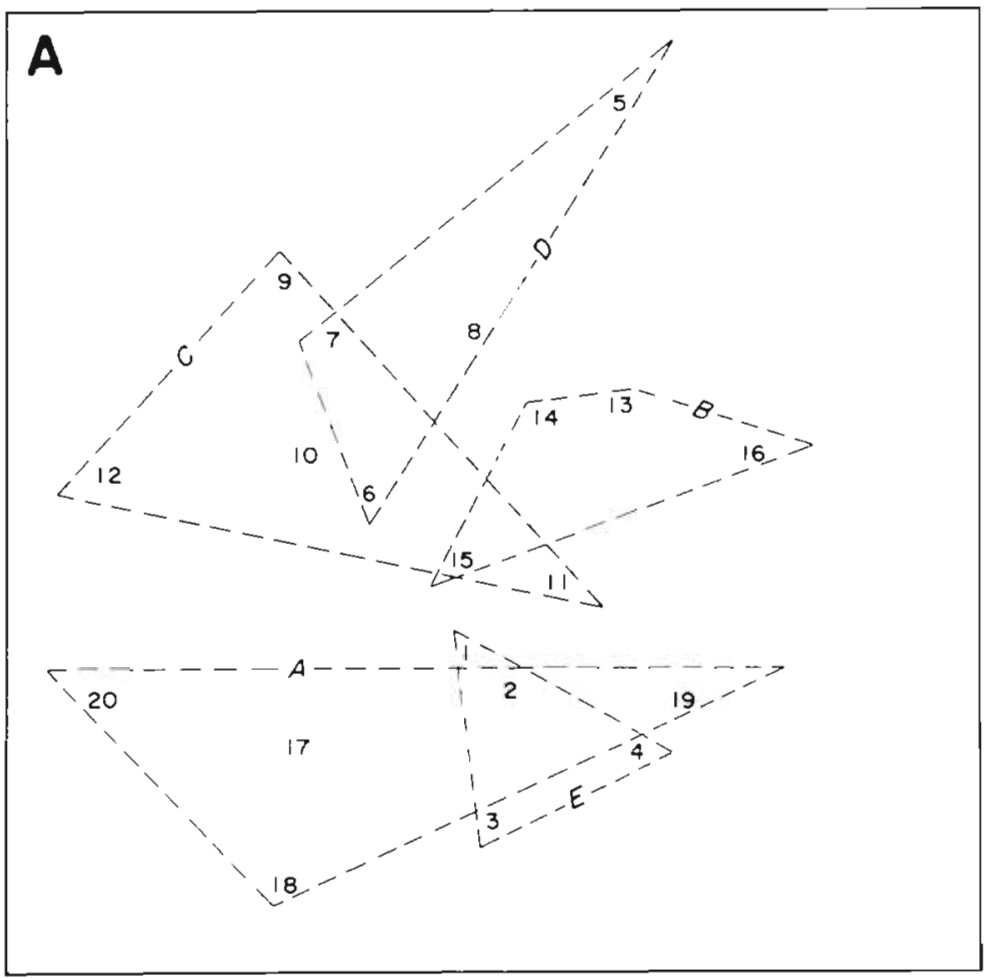

\section{B}

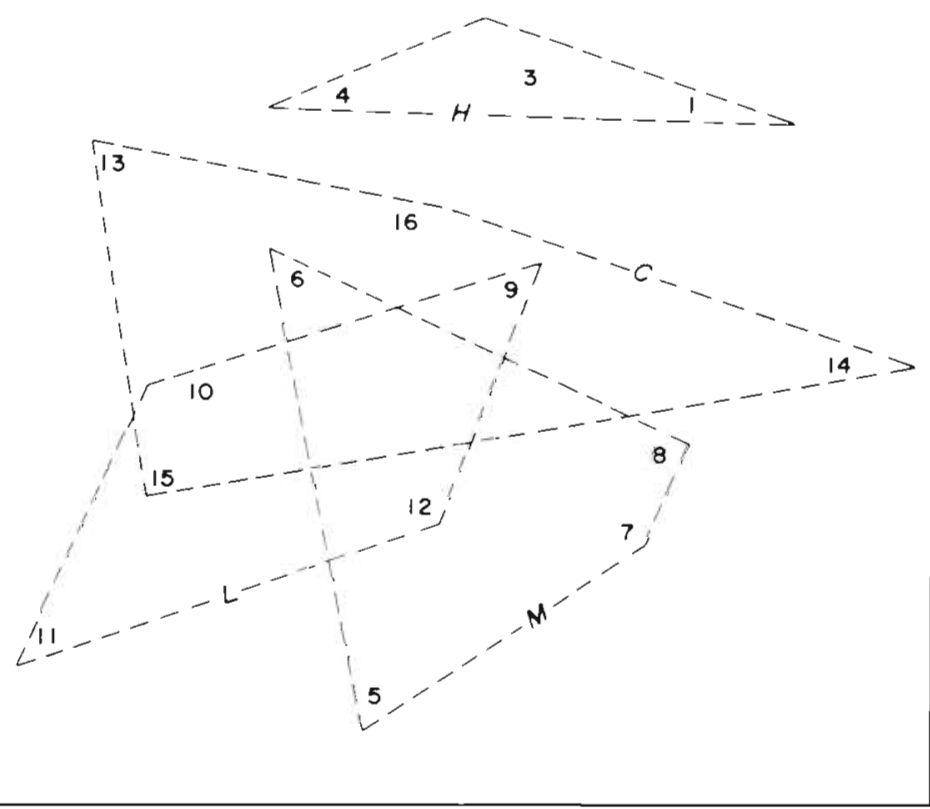

Fig. 4. MDS plots illustrating similarities between size-spectra of 4 replicate samples from 5 fjord sites (A), and 4 mesocosm basins (B). The closer 2 replicates are to each other the more similar are their size-spectra. Groups of samples from the same site/ basin are outlined and identified. C: control, L: low, M: medium, H: high-dose mesocosm basins 
one proceeds from Field site $F$ to Site A. Site $E$ is anomalous in this regard confirming that the factors involved in dctcrmining trends in biundass-size spectra are more complex than mere proximity to known pollution sources. Fig. 3, however, indicates that the overall trend of higher biomass at the outer sites - compared with the inner sites - is common to bacteria, meiofauna and macrofauna. Within the meiofauna, biomass levels in the outer sites are similar to those in the mesocosm basins, both being higher than those in the inner fjord sites. Again, this is a general pattern across the entire size spectrum including bacteria and macrofauna.

The most complete data collected in this study are for the macrofauna, covering the size range 512 to 32768 $\mu \mathrm{m}$ ESD. Although the data are based on mean wet weights of species or other taxonomic populations, Figs. 1 and 2 indicate that there is enough detail to warrant further analysis. Along with generally lower biomass levels, the inner fjord sites also appear to have more pronounced biomass 'troughs' in the 512 to 1024 $\mu \mathrm{m}$ region than the outer fjord and mesocosm samples. The mesocosm samples in general reveal less of a tendency to increasing biomass with larger size class than either inner or, especially, outer fjord samples (Fig. 3).

For both mesocosm and field samples, macrofaunal data were collected in a manner suitable for analysis of differences among their biomass-size spectra using MDS. Fig, 4 illustrates MDS plots obtained from 4 th root transformed biomass values, in size classes 512 to $32768 \mu \mathrm{m}$, in field (Fig. 4A) and mesocosm (Fig. 4B) samples. On these 2-dimensional MDS plots, proximity of replicates implies similarity of biomass size-spectra. Groups of samples from the same field site or from the same mesocosm treatment are outlined and labelled. Summaries of pairwise differences in ANOSIM tests on the 2 groups of samples are given in Table 1 . Field and mesocosm samples were not compared with each other in this analysis.

Overall, MDS analysis of the biomass-size spectra of

Table 1. Summary of ANOSIM tests on macrofaunal biomasssize spectra similarities, testing for pairwise differences among Field sites $\mathrm{A}$ to $\mathrm{E}$ and among control (C), low (L), medium $(M)$ and high-dose $(H)$ mesocosm basin

\begin{tabular}{|c|c|c|c|c|c|c|c|c|}
\hline & \multicolumn{4}{|c|}{ Field sites } & & \multicolumn{3}{|c|}{ Mesocosm basins } \\
\hline & $\mathrm{B}$ & $\mathrm{C}$ & $\mathrm{D}$ & $\mathrm{E}$ & & $\mathrm{L}$ & $\mathrm{M}$ & $\mathrm{H}$ \\
\hline A. & $\cdot$ & + & $\cdot$ & $\cdot$ & $\mathrm{C}$ & ns & ns & + \\
\hline B & & ns & • & $\cdot$ & L & & ns & ns \\
\hline $\mathrm{C}$ & & & ns & + & M & & & + \\
\hline D & & & & $\cdot$ & & & & \\
\hline
\end{tabular}

the field sites reflects patterns similar to those exhibited by MDS analyses of abundances of species and higher taxa (Gray et al. 1988, Heip et al. 1988). In Fig. 4A, Sites $A$ and $E$ clearly separate from $B, C$ and $D$, as indicated also by ANOSIM tests (Table 1); $\mathrm{A}$ and $\mathrm{E}$ do not however, appear distinct as they did for the equivalent macrofaunal species-based MDS plots (Fig, 2a,b of Gray et al. 1988). Though depth-related differences are likely to play an important part in defining this picture ( $\mathrm{E}: 22 \mathrm{~m}, \mathrm{~A}: 75 \mathrm{~m}, \mathrm{~B}, \mathrm{C}, \mathrm{D}: 99-113 \mathrm{~m}$ ), there is some support for the suggestion (Gray 1982) of a trend to reduced average size within macrofauna in polluted sediments. However, it would seem that this trend cannot be generalized to microbial and meiofaunal size ranges, though the proportion of meiofaunal biomass relative to that of macrofauna was greater in sediments from both the polluted field sites and the high dose mesocosm basin than in 'reference' sediments. MDS analysis of the field sites (Fig. 4A) confirms the observation (Fig. 1) that, in terms of biomass levels in the smaller macrofaunal size classes, Sites A and E are more similar to each other than to the intermediate sites.

In the mesocosm study, nominal dosing levels appeared to be only weakly related to observable trends in the biomass-size spectra, with the high-dose treatment appearing to differ from the other 3 treatments visually in the MDS plot, though not strongly in the ANOSIM test (Fig. 4B, Table 1). Again, this result is similar to results of MDS using abundances of species or higher taxa in the mesocosm treatments (Gray et al. 1988, Warwick et al. 1988).

\section{CONCLUSIONS}

While the taxonomic studies of meiofauna (Heip et al. 1988, Warwick et al. 1988) and macrofauna (Gray et al. 1988), and the microbial biomass studies (Schwinghamer 1988) carried out during the GEEP Workshop generally corroborate previous work on the effects of pollution on marine benthic communities (e.g. Grassle et al. 1981, Elmgren \& Frithsen 1982, Frithsen et al. 1985), there is no similar basis for comparison of the effects of pollutants on biomass-size spectra. However, the present results indicate that patterns of correlations of species abundances, abundances of higher taxa, and biomass-size spectra with environmental variables may all be similar. Thus, resolution of pollution-induced changes in community structure may be as great in non-taxonomic analyses, such as the present size-structure approach, as in the more skilled and time-consuming analysis of species abundances. This suggestion has especially important implications for base-line and monitoring studies in regions where the fauna is not 
well known or where taxonomic expertise is not available for such work. This is not to suggest that sizebased models of community structure can replace taxonomically-based models but only that, for some ecological problems, the former may provide sufficient insight for the purpose, and may answer the question 'Is further study required?'.

\section{LITERATURE CITED}

Bakke, T., Follum, O. A., Moe, K. A., Sørensen, K. (1988). The GEEP Workshop: mesocosm exposures. Mar. Ecol. Prog. Ser. 46: $13-18$

Clarke, K. R., Green. R. H. (1988). Statistical design and analysis for a 'biological effects' study. Mar Ecol. Prog. Ser. 46: 213-226

Elmgren, R., Frithsen, J. B. (1982). The use of experimental ecosystems for evaluating the environmental impact of pollutants: A comparison of an oil spill in the Baltic Sea and two long-term, low level oil addition experiments in mesocosms. In: Grice, G. D., Reeve, M. R. (eds.) Marine mesocosms - biological and chemical research in experimental ecosystems. Springer-Verlag, New York, p. $153-165$

Follum, O. A., Moe, K. A. (1988). The GEEP Workshop: field sampling. Mar. Ecol. Prog. Ser. 46: 7-12

Frithsen, J. B., Elmgren, R., Rudnick, D. T. (1985). Responses of benthic meiofauna to long-term, low-level additions of No. 2 fuel oil. Mar. Ecol. Prog. Ser. 23: 1-14

Gerlach, S. A., Hahn, A. E., Schrage, M. (1985). Size spectra of benthic biomass and metabolism. Mar. Ecol. Prog. Ser. 26: $161-173$
Grassle, J. F., Elmgren, R., Grassle, J. P. (1981). Response of benthic communities in MERL experimental ecosystems to low level, chronic additions of No. 2 fuel oil. Mar. environ. Res. 4: $279-297$

Gray, J. S. (1982). Effects of pollutants on ecosystems. Neth. J Sea Res. 16: 424-443

Gray, J. S., Aschan, M., Carr, M. R., Clarke, K. R., Green, R H., Pearson, T. H., Rosenberg R., Warwick, R. M. (1988) Analysis of community attributes of the benthic macrofauna of Frierfjord/Langesundfjord and in a mesocosm experiment. Mar Ecol. Prog. Ser. 46: 151-165

Hargrave, B. T., Thiel, H. (1983). Assessment of pollutioninduced changes in benthic community structure. Mar. Pollut. Bull. 14: 41-46

Heip, C., Warwick, R. M., Carr, M. R., Herman, P. M. J., Huys, R., Smol N., Van Holsbeke, K. (1988). Analysis of community attributes of the benthic meiofauna of Frierfjord/ Langesundfjord. Mar. Ecol. Prog. Ser. 46: 171-180

Schwinghamer, P. (1983). Generating ecological hypotheses from biomass spectra using causal analysis: a benthic example. Mar. Ecol. Prog. Ser. 13: 151-166

Schwinghamer, P. (1985). Observations on size-structure and pelagic coupling of some shelf and abyssal benthic communities. In: Gibbs, P. E. (ed.) Proc. 19th European Marine Biological Symposium. Cambridge University Press, Cambridge, p. $347-359$

Schwinghamer, P. (1988). Influence of pollution along a natural gradient and in a mesocosm experiment on sediment microbial numbers and biomass. Mar. Ecol. Prog. Ser. 46: 193-197

Warwick, R. M., Carr, M. R., Clarke, K. R., Gee J. M., Green, R.H. (1988). A mesocosm experiment on the effects of hydrocarbon and copper pollution on a sublittoral softsediment meiobenthic community. Mar. Ecol. Prog. Ser. 46: $181-191$ 